ACTA UNIVERSITATIS LODZIENSIS

FOLIA LITTERARIA POLONICA 2(32) 2016

http://dx.doi.org/10.18778/1505-9057.32.06

Rafał Siekiera*

\title{
Paradygmat reporterski czy eseistyczny? - Kilka uwag o sprawozdaniu sportowym
}

Sprawozdanie tradycyjnie zaliczane jest do gatunków informacyjnych. Wystarczy jednak pobieżne zapoznanie się $\mathrm{z}$ definicjami proponowanymi przez poszczególnych badaczy, by dostrzec tendencję do pomijania cech charakterystycznych dla sprawozdań sportowych.

Celem niniejszego opracowania jest przyjrzenie się współczesnym sprawozdaniom sportowym ${ }^{1} \mathrm{z}$ perspektywy genologicznej, próba określenia ich cech i miejsca w kontinuum gatunków.

Klasyczne koncepcje genologiczne sprawozdanie traktują dość jednoznacznie. Zdaniem Jacka Maziarskiego to „rzeczowa, zwięzła i aktualna relacja prasowa, radiowa lub telewizyjna z przebiegu jakiegoś zdarzenia [...]. Sprawozdanie jest uważane również za gatunek spokrewniony z informacją [...]"2. O podobieństwie do informacji prasowej decyduje zastosowanie podobnych środków wyrazu i zwięzłość oraz rzeczowość w przedstawianiu przebiegu zdarzeń ${ }^{3}$. Podobne stanowisko prezentuje Kazimierz Wolny-Zmorzyński, który dodatkowo podkreśla konieczność zachowania chronologicznego porządku prezentowania faktów oraz bezstronności autora ${ }^{4}$. Marek Chyliński i Stefan Russ-Mohl nazywają sprawozdanie wręcz „dłuższą informacją”,

* Dr, e-mail: rafal.siekiera@onet.eu; Uniwersytet Łódzki, Wydział Filologiczny, Katedra Dziennikarstwa i Komunikacji Społecznej; ul. Pomorska 171/173, 90-236 Łódź.

${ }^{1}$ Publikacje prasowe brane pod uwagę w badaniu określam jako sprawozdania, choć niekiedy można spotkać również określenie „relacja”. O rozróżnieniach terminologicznych dotyczących sprawozdań i relacji sportowych zob.: B. Grochala, Komentarz (sportowy), relacja (sportowa), sprawozdanie (sportowe) - przeglad stanowisk, „Acta Universitatis Lodziensis. Folia Litteraria Polonica" 2012, nr 3, s. 95-105.

2 J. Maziarski, Sprawozdanie, [w:] Encyklopedia wiedzy o prasie, red. J. Maślanka, Zakład Narodowy im. Ossolińskich, Wrocław 1976, s. 224.

${ }^{3}$ Tamże, s. 224-225.

${ }^{4}$ Por. K. Wolny-Zmorzyński, Sprawozdanie, [w:] Stownik terminologii medialnej, red. W. Pisarek, Universitas, Kraków 2006, s. 201 oraz K. Wolny-Zmorzyński, A. Kaliszewski, Gatunki informacyjne, [w:] K. Wolny-Zmorzyński, A. Kaliszewski, W. Furman, Gatunki dziennikarskie. Teoria, praktyka, język, Wydawnictwa Akademickie i Profesjonalne, Warszawa 2009, s. 44.

${ }^{5}$ M. Chyliński, S. Russ-Mohl, Dziennikarstwo, Grupa Wydawnicza Polskapresse, Warszawa 2008, s. 63. 
a jego istotę widzą w szczegółowym przedstawianiu faktów (także w porządku chronologicznym).

Zbigniew Bauer wskazuje możliwość odejścia od układu czasowego na rzecz przyczynowo-skutkowego, jednak również zalicza sprawozdanie do gatunków informacyjnych, a za jego najważniejsze zadanie uważa przybliżenie odbiorcy przebiegu wydarzenia ${ }^{6}$.

Zdaniem Janiny Fras najistotniejszymi składnikami sprawozdania są opisy, streszczenia i partie porównawcze, odnoszące się do minionych wydarzeń?

Wymienione cechy rzeczywiście sytuują omawiany gatunek wśród form wypowiedzi należących do rodzaju informacyjnego. Zgodnie z wyznacznikami, jakie można znaleźć $\mathrm{w}$ literaturze ${ }^{8}$, teksty tego typu powstają w celu powiadamiania o faktach aktualnych i ważnych społecznie, a ponadto charakteryzują się dążeniem do obiektywizmu, rzetelności i ścisłości przekazu, unikaniem interpretacji zdarzeń oraz asertorycznością, którą można rozumieć jako prezentowanie samych faktów, pozbawione domysłów, ocen i domniemań. Na płaszczyźnie językowej gatunki informacyjne wyróżnia depersonalizacja przekazu, szablonowość, komunikatywność, precyzja oraz brak stylistycznej nadbudowy w postaci środków odwracających uwagę od treści (fakt jest ważniejszy niż sposób jego przekazania), uatrakcyjniających tekst bądź wpływających na odbiór informacji.

Przedstawione powyżej tradycyjne ujęcie nie przystaje do szczególnej odmiany sprawozdania, jaką jest sprawozdanie sportowe. Większość z wymienionych cech w przypadku tekstów dziennikarzy sportowych zostaje zepchnięta na margines lub wręcz nie ma zastosowania. Dotyczy to zarówno płaszczyzny merytorycznej, funkcjonalnej, jak i językowej.

Dla lepszego scharakteryzowania analizowanego gatunku przydatne są koncepcje genologiczne Edwarda Balcerzana ${ }^{9}$, Janiny Fras ${ }^{10}$ i, pośrednio, Marii Wojtak ${ }^{11}$.

\footnotetext{
${ }^{6}$ Por. Z. Bauer, Gatunki dziennikarskie, [w:] Dziennikarstwo i świat mediów, red. Z. Bauer, E. Chudziński, Universitas, Kraków 2010, s. 267.

7 J. Fras, Dziennikarski warsztat językowy, wyd. 2 popr. i uzup., Wydawnictwo UWr, Wrocław 2005, s. 86.

${ }^{8}$ Por. m. in.: J. Maziarski, Informacja, [w:] Encyklopedia wiedzy o prasie, s. 107-109; K. Wolny-Zmorzyński, A. Kaliszewski, dz. cyt., s. 37-86; M. Chyliński, S. Russ-Mohl, dz. cyt., s. 54-68; Z. Bauer, dz. cyt., s. 263-269; M. Wojtak, Gatunki prasowe, Wydawnictwo UMCS, Lublin 2004; J. Fras, dz. cyt., s. 82; A. Kozieł, Gatunki dziennikarskie - rodowód, cechy i funkcje, [w:] O warsztacie dziennikarskim, red. J. Adamowski, Oficyna Wydawnicza Aspra-JR, Warszawa 2002, s. 111; J. Wegner, Metoda systematyzowania form dziennikarskich, [w:] Metody i techniki badawcze w prasoznawstwie, t. 1, red. M. Kafel, Wydawnictwa UW, Warszawa 1969, s. 130-144; A. Wtorkiewicz, Stylistyka prasoznawcza - szkic problematyki i metod, [w:] Metody i techniki badawcze w prasoznawstwie, t. 3, red. M. Kafel, Wydawnictwa UW, Warszawa 1971, s. 114-121.

${ }^{9}$ E. Balcerzan, W stronę genologii multimedialnej, „Teksty Drugie. Teoria literatury, krytyka, interpretacja" 1999, nr 6, s. 7-24.

${ }^{10} \mathrm{~J}$. Fras, O typologii wypowiedzi medialnych i dziennikarskich, Wydawnictwo UWr, Wrocław 2013.

${ }^{11}$ M. Wojtak, dz. cyt.
} 
Próba jednoznacznego zaklasyfikowania sprawozdania sportowego do któregoś z tradycyjnie wyróżnianych rodzajów dziennikarskich skazana jest na niepowodzenie. Wynika to z faktu, że poszczególne teksty w różnym stopniu realizują założenia rodzajowe. Stąd też przydatność polimedialnej triady Balcerzana. Zgodnie z tą propozycją należałoby mówić o paradygmatach quasi-rodzajowych, wyróżnianych ze względu na dominantę illokucyjną. Zaliczają się do nich intencje: felietonowa (jej zadaniem jest krytyczny, zdroworozsądkowy i zabawowy przegląd stereotypów ${ }^{12}$ ), eseistyczna (jej cechy to m.in. kontemplacyjność i dyskursywnośćcis) i reporterska (,powiadomienie o faktycznym stanie rzeczy"14). Zgodnie z ich charakterystyką, przedstawioną przez autora, sprawozdanie należałoby zaliczyć do gatunków realizujących intencję reporterską. Biorąc jednak pod uwagę zebrany materiał badawczy, można uznać, że sprawozdanie sportowe wykracza poza ten paradygmat.

Dużo bardziej pomocna jest koncepcja, zgodnie z którą gatunki to pojęcia typologiczne, a więc abstrakcyjne wzorce. Konkretne teksty zbliżają się do nich $\mathrm{w}$ mniejszym lub większym stopniu, nigdy jednak nie realizują ich w pełni ${ }^{15}$. W związku z tym słuszne jest posługiwanie się pojęciami typów (idealnych i empirycznych) ${ }^{16}$. Zdaniem Fras przedmiotem badania mogą być zarówno abstrakcyjne konwencje (typy idealne), jak i konkretne wypowiedzi (typy empiryczne), będące ich realizacjami. Ponieważ kontinuum gatunków mowy oparte jest na zasadach podobieństwa rodzinnego ${ }^{17}$, teksty mogą odtwarzać więcej niż jeden wzorzec. Fras nazywa takie wypowiedzi wielogatunkowymi czy też heterogenicznymi ${ }^{18}$. Wydaje się, że takie jest właśnie sprawozdanie sportowe.

Nie ulega wątpliwości, iż informuje ono o pewnych faktach, które z całą pewnością można nazwać aktualnymi. Zwykle publikuje się je następnego dnia po zakończeniu wydarzenia, do którego się odnoszą. Zatem ze względu na te dwie cechy zbliżone są do paradygmatu reporterskiego. Odpowiadają również na podstawowe pytania dziennikarskie, choć niekoniecznie na wszystkie ${ }^{19}$, a porządek, w jakim to robią, w dużej mierze zależny jest od inwencji autorów.

${ }^{12}$ E. Balcerzan, dz. cyt., s. 23.

13 Tamże, s. 22.

14 Tamże, s. 21.

${ }^{15} \mathrm{O}$ gatunkach jako pojęciach typologicznych por. J. Maziarski, Metodologiczne problemy nauki o gatunkach dziennikarskich, [w:] Metody i techniki badawcze w prasoznawstwie, t. 1, s. 120.

${ }^{16}$ Por. S. Gajda, Gatunkowe wzorce wypowiedzi, [w:] Wspótczesny język polski, red. J. Bartmiński, Wydawnictwo UMCS, Lublin 2012, s. 255-268.

${ }^{17}$ Inspiracją dla tego typu twierdzeń były teorie Ludwiga Wittgensteina i Eleanor Rosch.

18 J. Fras, O typologii..., s. 116.

${ }^{19} \mathrm{~Np}$. pominięte mogą zostać odpowiedzi na pytania: gdzie?, kiedy?, jak? (w jaki sposób?), dlaczego? Dziennikarze nie zawsze wprost piszą o tym, gdzie odbył się mecz czy wyścig lub została stoczona walka (odbiorcy z reguły i tak już to wiedzą), zdarza się także brak informacji o sposobie, w jaki np. zdobyto bramkę. Zasób treściowy sprawozdania uzależniony jest w dużym stopniu od sprawności autora, spodziewanej objętości tekstu oraz przebiegu samego wydarzenia (im bardziej dynamiczne i obfitujące w ważne momenty, tym mniej miejsca na dokładne opisy). 
Sprawozdanie sportowe nie przestrzega także tradycyjnego schematu konstrukcyjnego informacji, tzw. odwróconej piramidy, choć poszczególne elementy tekstów pokrywają się z budową wiadomości.

Na podstawie analizy publikacji prasowych można w sprawozdaniach sportowych wyodrębnić następujące części schematu strukturalnego:

- nagłówek, zawierający najważniejszą informację, choć częściej sformułowany tak, by zaintrygować (czasem zastępowany zwykłym powiadomieniem o wyniku), np.: Kliczko znów zanudzi20.

- lid uzupełniający tytuł, podsumowujący sprawozdawane wydarzenie lub zwracający uwagę na jakiś jego fragment, np.: „Mistrz świata zasłużenie odniósł kolejne zwycięstwo, ale publiczności w nowojorskiej Madison Square Garden nie porwał"’21;

- korpus, czyli właściwe sprawozdanie z przebiegu wydarzenia ${ }^{22}$.

Nagłówki sprawozdań sportowych nie zawsze wprost informują o tym, co jest przedmiotem tekstu. Obok tytułów konkretnych, stosunkowo jasnych i zrozumiałych (takimi cechami wyróżniają się teksty informacyjne, jak choćby wiadomości $^{23}$ ), np. Obrona z żelaza dała zwycięstwo ${ }^{24}$, Real zabity golem Suareza ${ }^{25}$, Ligowy klasyk na remis ${ }^{26}$, współwystępują tajemnicze i oryginalne, np. Lawendowe barwy Wisty ${ }^{27}$, Bez znieczulenia ${ }^{28}$, Błogostawiona leworęczność ${ }^{29}$, Polskie grzmoty zatrzęsty Kaliforniq $q^{30}$, Coraz lepiej widać Europe $e^{31}$, Wieczór pod batem ${ }^{32}$. Głównym zadaniem tak dobranych tytułów nie jest przekazywanie skondensowanej informacji o wydarzeniu (choć do pewnego stopnia to robią), lecz zaintrygowanie czytelnika lub efektowne podsumowanie zawodów. To cecha odpowiadająca raczej wypowiedziom eseistycznym bądź felietonowym (w tym także recenzji).

Tajemniczość nagłówka sprawia, że nie realizuje on niektórych tradycyjnie przypisywanych tej pozycji tekstowej celów, m.in. może utrudniać interpretację całości wypowiedzi czy też wprowadzać odbiorcę w błąd co do jego tema-

\footnotetext{
${ }^{20}$ A. Wasik, Kliczko znów zanudził, „Sport” 2015, 27.04, s. 20.

${ }^{21}$ Tamże.

${ }^{22}$ Por. schemat budowy wiadomości prasowej zaprezentowany przez Marię Wojtak: „Struktura wzorca kanonicznego wiadomości [...] przedstawia się następująco:

- nagłówek powiadamiający zwięźle o zdarzeniu lub fakcie;

- streszczający lub hasłowy lid;

- korpus w kształcie sprawozdania lub relacji [...]" (M. Wojtak, dz. cyt., s. 79).

${ }^{23}$ Por. W. Pisarek, Nagłówki wiadomości w dziennikach, „Zeszyty Prasoznawcze” 1965, nr 1, s. 34

${ }^{24}$ W. Osiński, Obrona z żelaza dała zwycięstwo, „Przegląd Sportowy” 2015, 27.01, s. 2-3.

${ }^{25}$ D. Wołowski, Real zabity golem Suareza, „Gazeta Wyborcza” 2015, 24.03, s. 23.

${ }^{26}$ K. Ferszter, Ligowy klasyk na remis, „Gazeta Stołeczna” 2015, 16.03, s. 12.

${ }^{27}$ G. Wojowicz, Lawendowe barwy Wisty, „Przegląd Sportowy” 2015, 22.01, s. 10.

${ }^{28}$ D. Bizewski, Bez znieczulenia, „Sport” 2015, 16.03., s. 11.

${ }^{29}$ M. Żukowski, Błogosławiona leworęczność, „Rzeczpospolita” 2015, 2.06, s. A16.

${ }^{30}$ P. Osiak, Polskie grzmoty zatrzęsty Kalifornia, „Przegląd Sportowy” 2015, 20.04, s. 18-19.

${ }^{31}$ S. Szczepłek, Coraz lepiej widać Europę, „Rzeczpospolita” 2015, 15.06, s. A16.

${ }^{32}$ R. Werner, Wieczór pod batem, „Sport” 2015, 27.02, s. 3.
} 
tu lub kontekstu ${ }^{33}$. Jak zaznacza Ewa Wolańska, przewaga funkcji informacyjnej bądź pozyskującej zależy od przynależności gatunkowej wypowiedzij ${ }^{34}$. Ujęcie uwzględniające podobieństwo rodzinne i traktujące gatunki jako typy pozwala na postrzeganie tekstów jako mniej lub bardziej oddalonych od wzorca. Tekst z nagłówkiem intrygującym plasuje się więc dalej od centrum pola gatunkowego.

W takich warunkach ciężar powiadomienia czytelników o zdarzeniu przejmuje lid. W tekstach informacyjnych uzupełnia on tytuł, rozbudowuje zawarta w nim informację o najważniejsze szczegóły. W sprawozdaniu sportowym występują zaś zasadniczo lidy o dwojakim charakterze:

- informujące wprost o rezultacie zawodów (formą i funkcją zbliżają się do sygnałów $\left.\mathrm{w}^{35}\right), \mathrm{np}$. :

Alejandro Valverde wygrał klasyk Liege-Bastonge-Liege. Michał Kwiatkowski przyjechał na 21. miejscu ${ }^{36}$.

$\mathrm{Na}$ inaugurację mundialu w Katarze biało-czerwoni przegrali 26-2937.

- podsumowujące przebieg zawodów, np.:

PGE GKS - Zawisza 1:4. Po 11 minutach meczu beniaminek był na kolanach, z których wstał tylko na chwilę ${ }^{38}$.

To był wyjątkowo ponury spektakl. Bez widzów, bez dobrego scenariusza przewidującego zaskakujący zwrot akcji i z cicho opuszczoną kurtyną. Tak mistrzowie Polski pożegnali się wczoraj z Europą ${ }^{39}$.

Obok tych dwóch podstawowych funkcji niektóre lidy spełniają także dodatkowo zadanie wyjaśnienia zagadkowego tytułu, jak w poniższych przykładach:

\section{Lawendowe barwy Wisty}

Popisowa gra Jantel Lavender i efektowne zwycięstwo Wisły Can-Pack Kraków w grupie A Euroligi. W grupie B Energa pobrała lekcję od Fenerbahce ${ }^{40}$.

${ }^{33} \mathrm{O}$ funkcjach tytułów czyt. m.in. w: W. Pisarek, Poznać prasę po nagłówkach!, Ośrodek Badań Prasoznawczych RSW „Prasa”, Kraków 1967; K. Piotrowska, Tytuł artykułu i jego wpływ na rozumienie tekstu, „Zeszyty Prasoznawcze” 1983, nr 4, s. 45-51.

${ }^{34}$ E. Wolańska, Kompozycja i spójność wypowiedzi językowej. Strategiczne pozycje tekstowe, [w:] Praktyczna stylistyka nie tylko dla polonistów, red. E. Bańkowska, A. Mikołajczuk, Książka i Wiedza, Warszawa 2003, s. 126.

${ }^{35}$ Por. rozważania M. Wojtak dotyczące lidu wiadomości prasowej (dz. cyt., s. 79).

${ }^{36}$ O. Kwiatkowski, Hiszpan - król Ardenów, „Rzeczpospolita” 2015, 27.04., s. A14.

${ }^{37}$ P. Rozpara, Prezent dla Niemców, „Gazeta Wyborcza” 2015, 17-18.01, s. 42.

${ }^{38}$ T. Pomarkiewicz, Wybili GKS ekstraklasę z glowy, „Przegląd Sportowy” 2015, 1.06, s. 9.

${ }^{39}$ R. Werner, dz. cyt.

${ }^{40}$ G. Wojowicz, dz. cyt. 


\section{Dekada przerwana!}

Tyszanie po 10 latach zrealizowali marzenia swoich fanów ${ }^{41}$.

W pierwszym przykładzie z lidu czytelnik dowiaduje się, dlaczego Wisła Can-Pack Kraków ma lawendowe barwy. Jest to metafora nawiązująca do nazwiska najlepszej zawodniczki meczu, Jantel Lavender. W drugim przypadku zagadkowy tytuł Dekada przerwana! odnosi się do przełamania przez zespół GKS Tychy dziesięcioletniej serii sezonów ligowych zakończonych brakiem zwycięstwa w rozgrywkach. Co prawda ani nagłówek, ani lid nie wskazują, o jaki sport chodzi, jednak można się tego dowiedzieć z tytułu kolumny (Hokej) oraz fotografii przedstawiającej drużynę nowego mistrza Polski w hokeju na lodzie.

Cechą charakterystyczną lidów sprawozdań sportowych jest zdecydowane odejście od paradygmatu reporterskiego. Najczęściej mają charakter komentujący, podsumowujący lub wprost oceniający, zawierają też wypowiedzi uczestników zawodów (spełniające w istocie funkcję komentarzy). Przybierają tym samym postać lidów mieszanych bądź udramatyzowanych ${ }^{42}$, odpowiadających intencji eseistycznej:

Rzeszowianie dobitnie udowodnili siatkarzom Lotosu Trefla Gdańsk, kto jest faworytem finału ${ }^{43}$.

Andrzej Fonfara odniósł jeden z największych triumfów w historii polskiego boksu zawodowego ${ }^{44}$.

Robert Lewandowski przeszedł do historii, ale to jeszcze nie wymarzona drużyna, na którą czekamy ${ }^{45}$.

Podsumowując rozważania dotyczące inicjalnych partii tekstów, można uznać, że ze względu na dominujący w praktyce dziennikarskiej sposób formułowania tytułów i lidów sprawozdanie sportowe zbliża się do tekstów o prymarnej intencji eseistycznej bądź felietonowej, w których nagłówki spełniają funkcję „nęcących czytelnika reklam,46, a pierwsze akapity zawierają komentarze, oceny, interpretacje zdarzeń.

Korpus sprawozdania sportowego, jeśli przyjąć cytowane na początku definicje gatunku, winien zawierać chronologiczny i bezstronny zapis ciągu pewnych zdarzeń. Skoro tekst dotyczy konkretnych zawodów sportowych, ich przebieg powinien być osią, wokół której całość wypowiedzi oscyluje. Co do

\footnotetext{
${ }^{41}$ W. Sowiński, Dekada przerwana!, „Sport” 2015, 3.04, s. 27.

${ }^{42}$ Por. M. Wojtak, dz. cyt., s. 83.

43 J. Bochenek, Nokaut na początek, „Sport” 2015, 16.04, s. 14.

${ }^{44}$ P. Osiak, dz. cyt.

${ }^{45}$ S. Szczepłek, dz. cyt.

${ }^{46}$ W. Pisarek, Nagłówki wiadomości..., s. 34.
} 
zasady, sprawozdawcy sportowi rzeczywiście odnoszą się do toku zawodów, choć z konieczności (ograniczone miejsce na łamach pisma) są to opisy mało drobiazgowe, obejmujące ogólne wrażenia (np. „mecz nabrał rumieńców, a oba zespoły miały jeszcze po kilka sytuacji do zmiany wyniku"47) i tylko wybrane fragmenty zdarzenia (np. gole, kontuzje, przełomowe zdaniem dziennikarza momenty wyścigu itp.).

Zdarza się jednak stosunkowo często, że w sprawozdaniu znaleźć można jedynie nieliczne odniesienia do akcji rozumianej jako łańcuch następujących po sobie faktów. Głównym tematem wypowiedzi dziennikarza stają się wówczas informacje poboczne, np. dotyczące problemów kadrowych danego zespołu, pogłębiającego się kryzysu formy zawodników bądź wpływu wyniku na sytuację w tabeli rozgrywek. Sprawozdawca odnosi się do zawodów bardzo skrótowo, skupiając się na poszukiwaniu przyczyn ostatecznego rezultatu (charakterystyczne dla paradygmatu eseistycznego). Partie komentujące mogą się wówczas stać dominantą sprawozdania.

Część zasadnicza wypowiedzi sprawozdawcy sportowego może zatem zawierać zarówno sam zapis następujących po sobie faktów, jak i elementy dodatkowe, np. cytaty z wypowiedzi zawodników, sędziów (rzadziej - ze względu na zakazy komentowania własnych decyzji przez arbitrów) i trenerów, a oprócz nich także informacje kontekstowe, dotyczące m.in. rekordów, jubileuszy, kontuzji, sytuacji w tabeli rozgrywek, zachowań kibiców itp.

Język sprawozdań sportowych również wykracza poza typowo informacyjną neutralność ${ }^{48}$. Widać to przede wszystkim w wyraźnej obecności autora. Co prawda sprawozdawcy nie posługują się formami pierwszej osoby (dominuje narracja trzecioosobowa), jednak ujawniają się poprzez stosowanie słownictwa wartościującego i oceniającego, np.:

W Prima Aprilis jastrzębianie, prowadzeni przez trenera Roberta Kalabera nie mieli prawa pokonać na swoim lodowisku zdobywców Pucharu Polski, bo zagrali katastrofalnie w obronie. O pomstę do nieba wołały zwłaszcza zagrania Tomaša Protivnego, który wczoraj stanowil piątą kolumnę w zespole $\mathrm{JKH}^{49}$.

Tego zwycięstwa nie byłoby jednak też bez świetnej postawy walecznego jak zwykle Michała Kubiaka, który serią zagrywek wyprowadził zespół na prowadzenie w drugim, przełomowym secie, bez bloków i ataków rewelacyjnego debiutanta Mateusza Bieńka i dobrej gry Mateusza Miki, który podczas zagranicznego tournée miewał gorsze momenty ${ }^{50}$.

${ }^{47}$ Z. Cieńciała, Stadiony świata!, „Sport” 2015, 7-8.03, s. 3.

${ }^{48}$ Oczywiście mowa tu o neutralności jedynie w przybliżeniu.

${ }^{49}$ W. Sowiński, Minuta walki to za mało, „Przegląd Sportowy” 2015, 2.04, s. 19.

${ }^{50}$ K. Drąg, Twierdza Teheran zdobyta, „Przegląd Sportowy” 2015, 29.06, s. 14. 
Uwagę zwraca również częste posługiwanie się słownictwem potocznym, nierzadko o charakterze metaforycznym:

Wczorajsze spotkanie, które rozpoczynało trzecią serię rundy rewanżowej, było starciem dwóch ,gorących" drużyn - Zagłębie wygrało sześć poprzednich spotkań, Legia w niezłym stylu pokonała u siebie silne Miasto Szkła Krosno i Znicz Basket Pruszków ${ }^{51}$.

Inaki Astiz ze złości wykopal piłkę w trybuny, pozostali warszawiacy zastygli w niedowierzaniu. [...] Stało się coś, w co wierzyli nieliczni - Legia pękła ${ }^{52}$.

Choć wysoką frekwencję potocyzmów w sprawozdaniach sportowych można tłumaczyć faktem, że duża ich część zalicza się do żargonu, znanego zarówno sportowcom, dziennikarzom, jak i kibicom, to oddala ona gatunek od wymogu neutralności stylistycznej języka.

Podobny, żargonowy i potoczny charakter ma frazeologia szeroko wykorzystywana przez sprawozdawców sportowych:

I już w 82 sek. drugi atak tak rozegrał akcję ofensywną, że zamykający ją Rzeszutko do pustej bramki dopelnil tylko formalności ${ }^{53}$.

Nasz zespół postawil mur, w którym twardzi Skandynawowie długo nie mogli znaleźć dziury ${ }^{54}$.

Frazeologizmy występujące $\mathrm{w}$ badanym materiale przenoszą ładunki emocjonalne. Pozwalają nadawcom na przyjmowanie roli komentatorów omawianych zdarzeń, ale także ekspertów (znajomość nieoficjalnego języka sportu, umiejętność dokonania oceny danego zagrania bądź możliwości sportowca). Autorzy tekstów przestają być wówczas jedynie obserwatorami zdającymi sprawę z przebiegu wydarzeń, czego wymaga od nich konwencja informacyjna.

Role, w jakie wcielają się nadawcy sprawozdań sportowych, oddalają gatunek od wzorca gatunkowego. Rodzą także pytania o podstawowe funkcje, jakie spełnia tekst. Gdyby traktować sprawozdanie sportowe jak każde inne, jego najważniejszym zadaniem byłoby poinformowanie odbiorców o przebiegu danego wydarzenia (meczu, walki, wyścigu itp.). Analiza sprawozdań publikowanych w prasie wskazuje, że w praktyce raportowanie z zawodów schodzi na dalszy plan. Uwypuklone zostają natomiast elementy komentatorskie, w których autorzy interpretują, oceniają, podsumowują i wyrażają własne opinie. Interpretująco-oceniające aspekty tekstu przeplatają się z podawaniem faktów (nie zawsze

\footnotetext{
${ }^{51}$ Ł. Cegliński, Legia przegrała z Zagłębiem, „Gazeta Stołeczna” 2015, 17-18.01, s. 16.

${ }^{52}$ P. Zych, Lech po liftingu Skorży, „Gazeta Wyborcza” 2015, 23.03., s. 27.

${ }^{53}$ J. Dusik, Awans i strata, „Sport” 2015, 6.03, s. 26.

${ }^{54}$ W. Osiński, dz. cyt.
} 
bezpośrednio dotyczących przebiegu rozgrywek) i stanowią integralną część wypowiedzi.

Jakie zatem funkcje należy przypisać sprawozdaniu sportowemu? Zdaniem Phila Andrewsa przede wszystkim jest to dostarczanie doświadczenia „z drugiej ręki” tym, którzy nie widzieli zawodów. Ponadto umożliwia ponowne przeżycie emocji odbiorcom, którzy byli na trybunach lub śledzili transmisję w telewizji/ radiu. Poza tym sprawozdanie pozwala czytelnikowi skonfrontować własne spostrzeżenia z ocenami dziennikarza, dostarcza analizy wydarzenia oraz informacji kreślących kontekst. Ostatnią z funkcji tego typu tekstów jest rozrywka ${ }^{55}$.

Andrews co prawda nie wskazuje hierarchii ważności poszczególnych funkcji, można jednak domniemywać, że umieszczając „doświadczenie z drugiej ręki" na pierwszym miejscu, nadaje mu rangę ważniejszą niż pozostałym.

Przeprowadzone na materiale prasowym ${ }^{56}$ badania wykazały, że autorzy nie ograniczają się do zapisu chronologicznej sekwencji zdarzeń. Na plan pierwszy wysuwa się podsumowanie i ocena, ujęta w formę możliwie skondensowaną. Stąd właśnie tendencja sprawozdawców do wybierania jedynie pewnych aspektów wydarzenia i opierania na nich całościowej interpretacji oraz opinii.

Zebrane dotąd wnioski z analizy pozwalają uznać sprawozdanie sportowe za gatunek realizujący w coraz większym stopniu intencję eseistyczną. Konkretne wypowiedzi mają charakter mieszany i można je umiejscowić na pograniczu dwóch paradygmatów. Być może, idąc za propozycjami Wojtak ${ }^{57}$, można je uznać za adaptacyjną odmianę wzorca gatunkowego, wykorzystującą elementy innego typu wypowiedzi - recenzji.

Według Stownika terminologii medialnej recenzja jest „omówieniem i/lub oceną dzieła artystycznego, naukowego lub innej publikacji będącej przedmiotem działania prawa autorskiego dokonanym w prasie lub innych środkach masowego przekazu"58. Podobnie jak recenzent, sprawozdawca dokonuje omówienia tematu swojego tekstu (są nim zawody sportowe). Nie musi ono być szczegółowe, co tłumaczyłoby wybór jedynie najważniejszych fragmentów zdarzenia, do których się odnosi. Ponadto, zarówno sprawozdanie, jak i recenzja stanowią wyraz stanowiska nadawcy. Obok partii informacyjnych zawierają uogólnione oceny, interpretacje, krytyczne analizy. Różnica polega na tym, że w recenzji elementy informacyjne odgrywają rolę jedynie pomocniczą, natomiast w sprawozdaniu, zgodnie z jego definicją, powinny być dominantą.

${ }^{55}$ Por. P. Andrews, Dziennikarstwo sportowe, przeł. M. Lorek, Wydawnictwo UJ, Kraków 2009, s. 51.

${ }^{56}$ Należy pamiętać, że sprawozdania publikowane są również w internecie. W tym przypadku, ze względu na brak ograniczeń dotyczących objętości tekstu, opisy zawodów są obszerniejsze i bardziej szczegółowe. Wciąż jednak zawierają liczne elementy komentatorskie i oceniające.

${ }^{57}$ M. Wojtak, dz. cyt.

${ }^{58}$ A. Kaliszuk, K. Wolny-Zmorzyński, Recenzja, [w:] Słownik terminologii medialnej, s. 181. 
Związek sprawozdania sportowego z recenzją ma również w pewnym sensie charakter historyczny. Sięgające przełomu XIX i XX wieku początki polskiego dziennikarstwa sportowego charakteryzowały się m.in. nieuporządkowaniem terminologicznym. Gatunek, który dziś nazywamy sprawozdaniem, początkowo określano właśnie jako recenzję (bądź omówienie, a termin ten pojawia się w cytowanej już definicji recenzji), samych zaś sprawozdawców nazywano często recenzentami $^{59}$. Już wówczas dziennikarze mieli wyraźną tendencję do oceniania prezentowanych czytelnikom zawodów. Współcześnie komentowanie wydarzeń sportowych staje się w wielu przypadkach wręcz dominantą funkcjonalną wypowiedzi. Na poziomie realizacji można mówić o eseistyczności jako coraz wyraźniejszej dominancie illokucyjnej wypowiedzi.

\section{Źródła cytatów}

[autor nieznany], Po zawodach Wegry - Polska, „Przegląd Sportowy” 1922, 6.01, s. 8.

Bizewski D., Bez znieczulenia, „Sport” 2015, 16.03., s. 11.

Bochenek J., Nokaut na początek, „Sport” 2015, 16.04, s. 14.

Cegliński Ł., Legia przegrała z Zagłębiem, „Gazeta Stołeczna” 2015, 17-18.01, s. 16.

Cieńciała Z., Stadiony świata!, „Sport” 2015, 7-8.03, s. 3.

Drąg K., Twierdza Teheran zdobyta, „Przegląd Sportowy” 2015, 29.06, s. 14.

Dusik J., Awans i strata, „Sport” 2015, 6.03, s. 26.

Ferszter K., Ligowy klasyk na remis, „Gazeta Stołeczna” 2015, 16.03, s. 12.

Kwiatkowski O., Hiszpan - król Ardenów, „Rzeczpospolita” 2015, 27.04., s. A14.

Osiak P., Polskie grzmoty zatrzęsty Kalifornia, „Przegląd Sportowy” 2015, 20.04, s. 18-19.

Osiński W., Obrona z żelaza dała zwycięstwo, „Przegląd Sportowy” 2015, 27.01, s. 2-3.

Pomarkiewicz T., Wybili GKS ekstraklasę z głowy, „Przegląd Sportowy” 2015, 1.06, s. 9.

Rozpara P., Prezent dla Niemców, „Gazeta Wyborcza” 2015, 17-18.01, s. 42.

Sowiński W., Dekada przerwana!, „Sport” 2015, 3.04, s. 27.

Sowiński W., Minuta walki to za mało, „Przegląd Sportowy” 2015, 2.04, s. 19.

Szczepłek S., Coraz lepiej widać Europę, „Rzeczpospolita” 2015, 15.06, s. A16.

Wasik A., Kliczko znów zanudzit, „Sport”2015, 27.04, s. 20.

Werner R., Wieczór pod batem, „Sport” 2015, 27.02, s. 3.

Wojowicz G., Lawendowe barwy Wisty, „Przegląd Sportowy” 2015, 22.01, s. 10.

Wołowski D., Real zabity golem Suareza, „Gazeta Wyborcza” 2015, 24.03, s. 23.

Zych P., Lech po liftingu Skorży, „Gazeta Wyborcza” 2015, 23.03., s. 27.

Żukowski M., Błogosławiona leworęczność, „Rzeczpospolita” 2015, 2.06, s. A16.

${ }^{59}$ Por.: „Ocena gry poszczególnych graczy polskich w prasie węgierskiej sprawiła naszym recenzentom niemałą zapewne radość; nasz ogół sportowy bowiem miał sposobność przekonać się, że nawet o wiele bardziej fachowi niż u nas sprawozdawcy nie tylko różnią się w swych zdaniach, lecz nawet w wielu punktach ocena ich jest błędną" ([autor nieznany], Po zawodach Węgry - Pol$s k a$, „Przegląd Sportowy” 1922, 6.01, s. 8). Przykład ten dowodzi, że terminy „sprawozdawca” $\mathrm{i}$,recenzent” traktowano zamiennie. 


\section{Bibliografia}

Andrews P., Dziennikarstwo sportowe, przeł. M. Lorek, Wydawnictwo UJ, Kraków 2009.

Balcerzan E., W strone genologii multimedialnej, „Teksty Drugie. Teoria literatury, krytyka, interpretacja" 1999, nr 6, s. 7-24.

Bauer Z., Gatunki dziennikarskie, [w:] Dziennikarstwo i świat mediów, red. Z. Bauer, E. Chudziński, Universitas, Kraków 2010, s. 255-280.

Chyliński M., Russ-Mohl S., Dziennikarstwo, Grupa Wydawnicza Polskapresse, Warszawa 2008.

Fras J., Dziennikarski warsztat językowy, wyd. 2 popr. i uzup., Wydawnictwo UWr, Wrocław 2005.

Fras J., O typologii wypowiedzi medialnych i dziennikarskich, Wydawnictwo UWr, Wrocław 2013.

Gajda S., Gatunkowe wzorce wypowiedzi, [w:] Wspótczesny język polski, red. J. Bartmiński, Wydawnictwo UMCS, Lublin 2012, s. 255-268.

Grochala B., Komentarz (sportowy), relacja (sportowa), sprawozdanie (sportowe) - przeglad stanowisk, „Acta Universitatis Lodziensis. Folia Litteraria Polonica” 2012, nr 3, s. 95-105.

Kaliszuk A., Wolny-Zmorzyński K., Recenzja, [w:] Słownik terminologii medialnej, red. W. Pisarek, Universitas, Kraków 2006, s. 181.

Kozieł A., Gatunki dziennikarskie - rodowód, cechy i funkcje, [w:] O warsztacie dziennikarskim, red. J. Adamowski, Oficyna Wydawnicza Aspra-JR, Warszawa 2002, s. 109-127.

Maziarski J., Informacja, [w:] Encyklopedia wiedzy o prasie, red. J. Maślanka, Zakład Narodowy im. Ossolińskich, Wrocław 1976, s. 107-109.

Maziarski J., Metodologiczne problemy nauki o gatunkach dziennikarskich, [w:] Metody i techniki badawcze w prasoznawstwie, t. 1, red. M. Kafel, Wydawnictwa UW, Warszawa 1969, s. 113-129.

Maziarski J., Sprawozdanie, [w:] Encyklopedia wiedzy o prasie, red. J. Maślanka, Zakład Narodowy im. Ossolińskich, Wrocław 1976, s. 224.

Piotrowska K., Tytuł artykułu i jego wptyw na rozumienie tekstu, „Zeszyty Prasoznawcze” 1983, nr 4, s. 45-51.

Pisarek W., Nagłówki wiadomości w dziennikach, „Zeszyty Prasoznawcze” 1965, nr 1, s. 31-48.

Pisarek W., Poznać prasę po nagłówkach!, Ośrodek Badań Prasoznawczych RSW „Prasa”, Kraków 1967.

Wegner J., Metoda systematyzowania form dziennikarskich, [w:] Metody i techniki badawcze w prasoznawstwie, t. 1, red. M. Kafel, Wydawnictwa UW, Warszawa 1969, s. 130-144.

Wojtak M., Gatunki prasowe, Wydawnictwo UMCS, Lublin 2004.

Wolańska E., Kompozycja i spójność wypowiedzi językowej. Strategiczne pozycje tekstowe, [w:] Praktyczna stylistyka nie tylko dla polonistów, red. E. Bańkowska, A. Mikołajczuk, Książka i Wiedza, Warszawa 2003, s. 119-147.

Wolny-Zmorzyński K., Kaliszewski A., Gatunki informacyjne, [w:] K. Wolny-Zmorzyński, A. Kaliszewski, W. Furman, Gatunki dziennikarskie. Teoria, praktyka, język, Wydawnictwa Akademickie i Profesjonalne, Warszawa 2009, s. 37-86.

Wolny-Zmorzyński K., Sprawozdanie, [w:] Stownik terminologii medialnej, red. W. Pisarek, Universitas, Kraków 2006, s. 201.

Wtorkiewicz A., Stylistyka prasoznawcza - szkic problematyki i metod, [w:] Metody i techniki badawcze w prasoznawstwie, t. 3, red. M. Kafel, Wydawnictwa UW, Warszawa 1971, s. $114-121$. 
Rafał Siekiera

Reporter or essay paradigm? - A few remarks about sports reports

\section{(Summary)}

The article attempts to decide whether sports reports are more about news or commentary. Based on an analysis of press material, the author examines various characteristics of the genre and tries to determine their compatibility with the news canon. As the analysis shows, contemporary sports reports are less about news and more about commentary, interpretation or evaluation. Journalists tend to sum up the contest and briefly describe the course of events. This makes sports reports similar to press comment and review.

Keywords: sports report, sports journalism, journalistic genres. 